\title{
PERBANDINGAN KINERJA REKSADANA SYARIAH DAN REKSADANA KONVENSIONAL \\ (PADA REKSADANA SAHAM DAN REKSADANA PENDAPATAN TETAP YANG TERDAFTAR DI BEI PERIODE 2010-2014)
}

\author{
Nurul Qomariah \\ Maheni Ika Sari \\ Dian Asih Budiarti \\ Prodi Manajemen Fakultas Ekonomi Universitas Muhammadiyah Jember \\ Jalan Karimata 49 Jember 68121 - Indonesia
}

\begin{abstract}
Interest of investors in making investments is to benefit from these activities and also expect funds invested will be stored securely and can take it back easily if needed. Mutual Funds is a new investment vehicle that have a risk that can be minimized, this is because the funds raised will be invested in various investment vehicles, such as stocks, bonds, or money market instruments and other securities. This study aims to determine differences in the performance of Islamic mutual funds with the performance of conventional mutual funds through the return and risk on the type of stock mutual funds and fixed income funds. The population in this study are all conventional mutual funds and Islamic mutual funds of stocks and fixed income active in the period 2010-2014, the population is known to fund as many as 42 conventional stock mutual funds and fixed income funds for conventional 93 mutual funds, mutual fund shares subsequently sharia as much 22 while fixed income funds as much as 8 sharia mutual funds. The sampling method using purposive sampling method. The number of samples for conventional stock mutual funds is 5, for a conventional fixed income funds sample number 5, for equity funds sharia sample number 5, and for fixed income funds sharia number of samples 3. The analytical method used is to test different methods of paired sample $t$-test. The results showed that there are significant differences between the average return and the conventional stock mutual funds average return of sharia mutual fund shares. As for the fixed income funds are also significant differences over conventional risk fixed income funds and fixed income funds sharia.
\end{abstract}

Keywords: equity funds, fixed income funds, Islamic mutual funds performance, the performance of conventional mutual funds.

\section{PENDAHULUAN}

Seiring meningkatnya kebutuhan manusia, membuat setiap orang harus memikirkan masa depan. Peningkatan kebutuhan tersebut tentunya harus diimbangi dengan peningkatan penghasilan, sebaliknya seringkali hal tersebut tidak diimbangi dengan penghasilan yang diperoleh ibarat kata

Korespondensi dengan Penulis:

Nurul Qomariah, HP +6281553182768

e-mail: qomariahn66@yahoo.com 


\section{Jurnal Keuangan dan Perbankan | KEUANGAN}

Vol. 20, No.3, September 2016: 417- 427

pepatah besar pasak daripada tiang. Kondisi tersebut mendorong orang untuk menyisihkan sebagian pendapatan dalam suatu wadah yang diharapkan akan meningkat nilainya pada masa mendatang. Kegiatan menempatkan uang pada suatu wadah (aktiva/asset keuangan) yang diharapkan akan meningkat nilainya di masa mendatang disebut kegiatan investasi (Nindyaswara, 2014).

Investasi dapat diartikan sebagai pengeluaran atau pembelanjaan penanam-penanam modal atau perusahaan untuk membeli barang-barang modal dan perlengkapan-perlengkapan produksi untuk menambah kemampuan memproduksi barang-barang dan jasa-jasa yang tersedia dalam perekonomian (Sukirno, 1997). Tujuan investor dalam melakukan investasi adalah memperoleh keuntungan dari kegiatan tersebut dan juga mengharapkan dana yang diinvestasikan akan tersimpan dengan aman dan dapat mengambil kembali dengan mudah jika diperlukan. Namum keuntungan yang diperoleh tersebut tentunya juga akan sebanding dengan risiko yang harus dihadapi oleh investor dimana return yang tinggi tentunya juga akan diikuti dengan risk yang tinggi pula (high risk high return) (Anwar, 2010).

Menghadapi kenyataan yang demikian, investor pada umumnya berupaya mencari jalan un- tuk dapat menekan risiko investasi hingga sekecil mungkin. Reksadana merupakan sarana investasi baru yang menjawab permasalahan di atas, dimana dengan reksadana risiko investasi dapat diperkecil karena dana yang terkumpul dari berbagai investor diinvestasikan di berbagai sarana investasi, seperti saham, obligasi, atau instrument pasar uang dan efek-efek lainnya.

Reksadana menurut undang-undang pasar modal No. 8 tahun 1995 merupakan wadah yang dipergunakan dalam rangka menghimpun dana dari masyarakat dalam pemodal untuk selanjutnya di investasikan dalam portofolio efek yang dilakukan oleh manajer investasi. Peminat reksadana semkin tinggi setiap tahunnya terbukti dalam grafik pertumbuhan reksadana dari 31 Oktober 2013 hingga 24 Desember 2014 yang di upload oleh situs Infivesta.

Grafik di atas menunjukan pertumbuhan peminat investor terhadap reksadana dalam periode 1 tahun. Seiring jumlah peminat yang meningkat, di Indonesia sendiri instrumen reksadana juga berkembang tidak hanya reksadana konvensional kini untuk memenuhi keinginan masyarakatnya yang notabene beragama islam tidak sedikit dari lembaga-lembaga keuangan berbasis syariah juga mengeluarkan reksadana syariah.

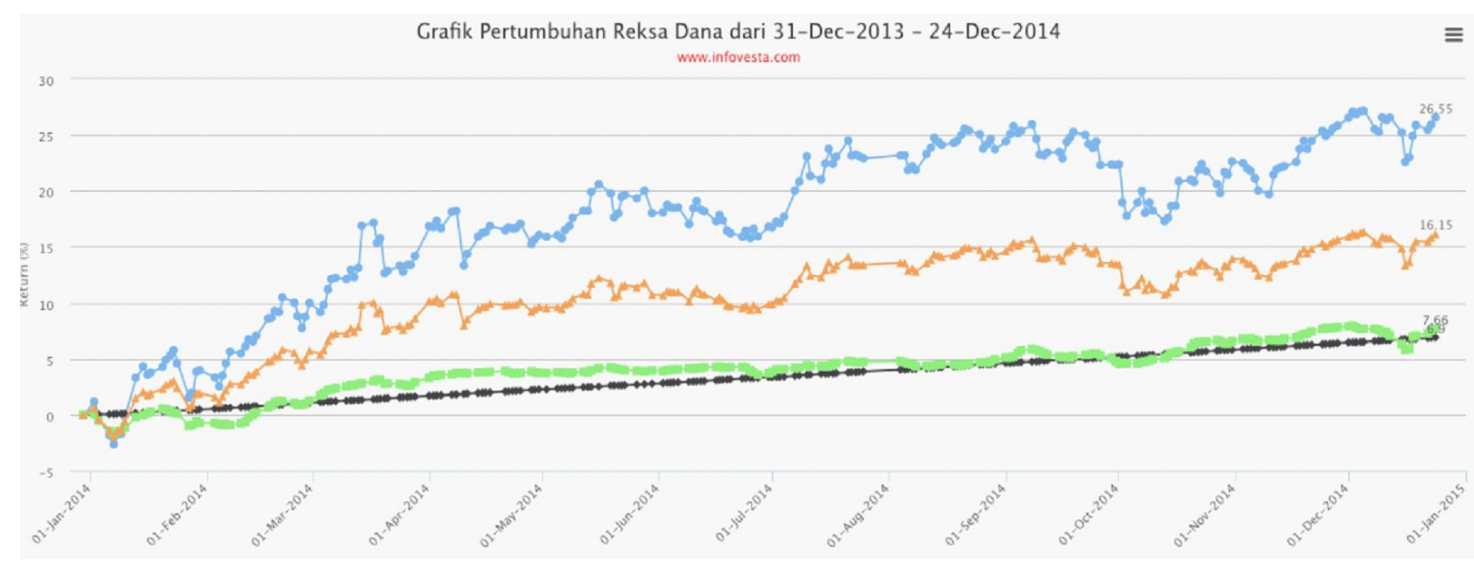

Gambar 1. Grafik Pertumbuhan Reksadana Sumber: www.invovesta.com 
Menurut Hayati dan Haruman (2006), pada dasarnya reksadana syariah sama dengan reksadana konvensional, yang membedakan adalah reksadana syariah memiliki kebijakan investasi yang berbasiskan kepada prinsip-prinsip islam. Instrumen yang dapat dipilih untuk masuk dalam portofolio investasi harus investasi berkategori halal. Dikatakan halal, jika pihak yang menerbitkan instrumen investasi tersebut tidak melakukan usaha yang bertentangan dengan prinsip-prinsip islam seperti contoh kegiatan usaha diatas tidak melakukan riba atau membungakan uang sedangkan dari segi peraturan, perlakuan serta pembagian hasilnya sama dengan reksadana konvensional.

Walaupun jumlah reksadana syariah tidak sebanyak reksadana konvensional namun pertumbuhanya pun juga semakin meningkat, OJK (Otoritas Jasa Keuangan) mencatat perkembangan reksadana syariah yang terus beranjak naik dari tahun 2003-2014, seperti dalam grafik berikut.

Menelaah dari grafik di atas menunjukkan semakin meningkatnya peminat reksadana syariah dari tahun 2003-2014 dan juga semakin banyaknya produk reksadana syariah yang bermunculan. Hal ini memicu semakin sulitnya masyarakat untuk memilih reksadana mana yang ingin dijadikan sebagai pilihan untuk berinvensatasi baik itu reksadana konvensional maupun syariah.

Tidak hanya itu berdasarkan portofolionya ada beberarapa jenis reksadana yang harus di ketahui ketika ingin berinvestasi pada reksadana yaitu, reksadana saham, reksadana pendapatan tetap, reksadana pasar uang, reksadana campuran. Semua jenis reksadana tersebut ada didalam reksadana konvenional maupun reksadana syariah.

Namun penelitian ini lebih menfokuskan pada reksadana saham dan reksadana pendapatan tetap, baik syariah maupun konvensional. Alasanya adalah adalah (1) reksadana saham merupakan jenis reksadana yang paling banyak diminati oleh para investor karena returnnya cukup tinggi, reksadana yang mayoritas berbasis saham masih paling banyak peminatnya. Berdasarkan data OJK per 31 Oktober, jumlah dana kelolaan reksadana saham ini mencapai Rp 90,59 triliun, atau 42,64\% dari keseluruhan dana. (2) Reksadana pendapatan

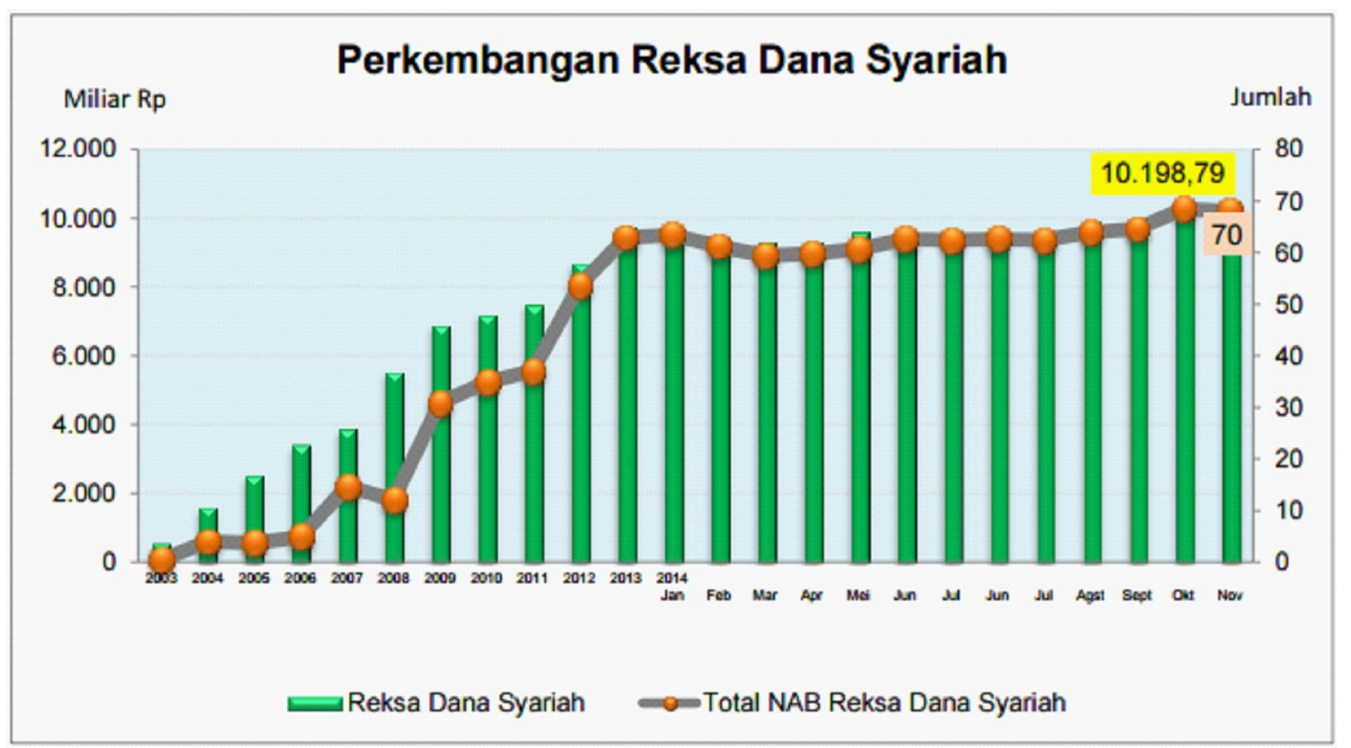

Gambar 2. Grafik Perkembangan Reksadana Syariah Sumber: http://www.ojk.go.id/data-statistik-syariah-reksadana 


\section{Jurnal Keuangan dan Perbankan | KEUANGAN}

Vol. 20, No.3, September 2016: 417- 427

tetap karena reksadana ini memiliki risiko yang relatif lebih rendah dengan tujuan investasi untuk menghasilkan return yang stabil. Bapepam menginfokan tingkat potensi risiko reksadana pendapatan tetap termasuk kategori menengah cenderung konservatif. Reksadana pendapatan tetap cocok untuk investor yang mengharapkan pendapatan tetap yang cukup stabil dari investasinya, dan tidak terlalu fluktuatif. Reksadana pendapatan tetap juga cocok jika penempatan dananya antara satu sampai tiga tahun. Sebab dalam jangka waktu tersebut reksadana pendapatan tetap berpotensi memberikan return lebih tinggi dari pada reksadana pasar uang.

Return dan resiko yang akan diterima, tetap menjadi pertimbangan pertama bagi investor untuk menanamkan modalnya. Tidak terkecuali investor muslim dalam memutuskan untuk menanamkan modalnya. Pada kenyataanya, masih banyak keraguan dari kaum awam atau return yang di terima dari reksadana syariah tidak besar atau menguntungkan di banding reksadana konvensional.

Penelitian yang dilakukan Hamzah dan Yohanes (2014) menghasilkan tidak ditemukanya perbedaan signifikan antara kinerja reksadana syariah dan reksadana konvensional dalam hal return dan risko walaupun kinerja reksadana syariah cenderung lebih rendah di bandingkan dengan kinerja reksadana konvensional pada jenis reksadana pendapatan tetap. Hal ini menarik apabila jenis yang digunakan dalam penelitian adalah dua reksadana yaitu reksadana saham dan reksadana pendapatan tetap untuk membandingkan kinerja antara reksadana syariah dan reksadana konvensional melalui return dan risiko dari kedua jenis reksadana tersebut. Sekaligus menjadi gambaran terbaru bagi para investor tentang perkembangan kinerja reksadana syariah dan reksadana konvensional di Indonesia sebelum memutuskan untuk menanamkan modalnya di reksadana. Putra dan Fauzie (2014) menyatakan bahwa tingkat pengembalian reksa dana syariah lebih baik daripada reksa dana konvensional, selain itu reksa dana syariah memiliki risiko yang lebih kecil daripada reksa dana konvensional. Rumintang dan Azhari (2014) dalam penelitiannya tentang perbedaan saham syariah dan saham konvensional menyatakan bahwa antara kinerja reksa dana saham konvensional dan syariah tidak memiliki perbedaan yang signifikan. Kartini dan Febriyanto (2011) menyatakan bahwa kinerja reksadana saham syariah tidak berbeda secara signifikan dengan kinerja reksa dana konvensional.

\section{HIPOTESIS}

Untuk meningkatkan return dalam berinvestasi, investor harus melakukan investasi yang menyebar pada berbagai instrumen pasar modal. Dengan membeli reksadana saham investor berkesempatan memperoleh return yang cukup tinggi oleh reksadana saham adalah reksadana yang paling banyak diminati oleh para investor. Namun disamping itu tidak semata-mata return yang tinggi pasti memliki risiko yang tinggi pula seperti yang di jelaskan oleh Supriyadi 2009. Reksadana saham yang memiliki risko yang tinggi tidak otomatis menghasilkan keuntungan yang lebih dari pada produk reksadana saham yyang tingkat risikonya kecil dan sebaliknya. Kemudian penelitian yang di lakukan oleh Hamzah dan Yohanes (2014) menggunakan uji beda menghasilkan tidak ditemukanya perbedaan signifikan antara kinerja reksadana syariah dan reksadana konvensional dalam hal return dan risiko walaupun kinerja reksadana syariah cenderung lebih rendah dibandingkan dengan kinerja reksadana konvensional melalui reksadana saham, dari penjelasan di atas dapat di simpulkan bahwa:

H1: Terdapat perbedaan yang signifikan antara kinerja reksadana syariah dan reksadana konvensional dengan return reksadana saham.

Kemudian untuk mengurangi tingkat risiko dalam berinvestasi reksadana pendapatan tetap dapat di jadikan pilihan bagi para investor yang 


\section{Perbandingan Kinerja Reksadana Syariah dan Reksadana Konvensional}

Nurul Qomariah, Maheni Ika Sari, \& Dian Asih Budiarti

takut akan mengambil risiko terlalu tinggi. Reksadana pendapatan tetap memiliki risiko yang relatif lebih rendah dengan tujuan investasi untuk menghasilkan return yang stabil. Supriyadi 2009 dalam penelitianya menjelaskan tentang kinerja reksadana pendapatan tetap, menemukan bahwa produk reksadana saham mempunyai tingkat return dan risiko yang bervariasi. Bapepam juga menginfokan tingkat potensi risiko reksadana pendapatan tetap termasuk kategori menengah cenderung konservatif. Reksadana pendapatan tetap cocok untuk investor yang mengharapkan pendapatan tetap yang cukup stabil dari investasinya, dan tidak terlalu fluktuatif. Dengan demikian dapat disimpulkan bahwa:

H2: Terdapat perbedaan yang signifikan antara kinerja reksadana syariah dan reksadana konvensional dengan risiko reksadana pendapatan tetap.

\section{METODE}

Populasi dalam penelitian ini adalah semua reksadana konvensional dan reksadana syariah jenis saham dan pendapatan tetap yang aktif pada periode 2010-2014 diketahui populasinya adalah untuk reksadana saham konvensional yaitu sebanyak 42 reksadana dan untuk reksadana pendapatan tetap konvensional yaitu 93 reksadana, selanjutnya reksadana saham syariah sebanyak 22 sedangkan reksadana pendapatan tetap syariah sebanyak 8 reksadana. Adapun sampel yang digunakan dalam penelitian ini di ambil secara purposive sampling, yaitu teknik pengambilan sampel sumber data dengan pertimbangan tertentu (Sugiyono, 2009). Jumlah sampel untuk reksadana saham konvensional adalah 5, untuk reksadana pendapatan tetap konvensional jumlah sampelnya 5, untuk reksadana saham syariah jumlah sampelnya 5, dan untuk reksadana pendatan tetap syariah jumlah sampelnya 3.Adapun kriteria penentuan sampel yang dipertimbangkan adalah sebagai berikut:

1. Reksadana saham dan reksadana pendapatan tetap konvensional yang dipilih adalah yang listed di periode (2010-2014).

2. Reksadana saham dan reksadana pendapatan tetap syariah yang dipilih adalah yang listed di periode (2010-2014).

3. Reksadana saham dan reksadana pendapatan tetap baik konvensional maupun syariah yang mempublikasikan NAB (Nilai Aktiva Bersih) secara umum per tahun dari tahun (2010-2014).

4. Untuk reksadana konvensional baik reksadana saham maupun pendapatan tetap di ambil 5 peringkat dengan NAB terbaik. Berdasarkan data kualifikasi di atas maka dapat dihasilkan sampel sebagai berikut:

\begin{tabular}{|c|l|c|}
\hline NO & \multicolumn{1}{|c|}{ REKSADANA SAHAM KONVENSIONAL } & JUMLAH REKSADANA \\
\hline 1 & Jumlah reksadana yang aktif dari periode 2010-2014 & 42 \\
\hline 2 & $\begin{array}{l}\text { Reksadana saham } \\
\text { yang mempublikasikan NAB } \\
\text { dari tahun (2010-2014). }\end{array}$ & 42 \\
\hline 3 & 5 peringkat dengan NAB terbaik & 5 \\
\hline 4 & Jumlah Total Sampel reksadana saham & 5 \\
\hline
\end{tabular}


Jurnal Keuangan dan Perbankan | KEUANGAN

Vol. 20, No.3, September 2016: 417-427

\begin{tabular}{|c|l|c|}
\hline NO & \multicolumn{1}{|c|}{ REKSADANA Pend.Tetap KONVENSIONAL } & JUMLAH REKSADANA \\
\hline 1 & Jumlah reksadana yang aktif dari periode 2010-2014 & 93 \\
\hline 2 & $\begin{array}{l}\text { Reksadana Pendapatan Tetap } \\
\text { yang mempublikasikan NAB } \\
\text { dari tahun (2010-2014). }\end{array}$ & 90 \\
\hline 3 & 5 peringkat dengan NAB terbaik & 5 \\
\hline 4 & Jumlah Total Sampel reksadana Pend.Tetap & 5 \\
\hline
\end{tabular}

\begin{tabular}{|c|l|c|}
\hline NO & \multicolumn{1}{|c|}{ REKSADANA SAHAM SYARIAH } & JUMLAH REKSADANA \\
\hline 1 & Jumlah reksadana yang aktif dari periode 2010-2014 \\
\hline 2 & $\begin{array}{l}\text { Reksadana Saham } \\
\text { yang mempublikasikan NAB } \\
\text { dari tahun (2010-2014). }\end{array}$ & 6 \\
\hline 3 & 5 peringkat dengan NAB terbaik & 5 \\
\hline 4 & Jumlah Total Sampel reksadana Saham & 5 \\
\hline
\end{tabular}

\begin{tabular}{|c|l|c|}
\hline NO & \multicolumn{1}{|c|}{ REKSADANA Pend.Tetap SYARIAH } & JUMLAH REKSADANA \\
\hline 1 & Jumlah reksadana yang aktif dari periode 2010-2014 & 8 \\
\hline 2 & $\begin{array}{l}\text { Reksadana Pendapatan Tetap } \\
\text { yang mempublikasikan NAB } \\
\text { dari tahun (2010-2014). }\end{array}$ & 3 \\
\hline 3 & 5 peringkat dengan NAB terbaik & 3 \\
\hline 4 & Jumlah Total Sampel reksadana Pend.Tetap & 3 \\
\hline
\end{tabular}

Uji hipotesis dilakukan dengan menggunakan uji Paired sampel $\mathrm{T}$ test (Uji beda sampel berpasangan), yaitu pengujian untuk mengetahui apakah ada perbedaan nilai dari satu sampel sebelum dan sesudah dilakukan perlakuan tertentu, namun menggunakan sampel yang sama dan pengambilan data 2 kali pada waktu yang berbeda.

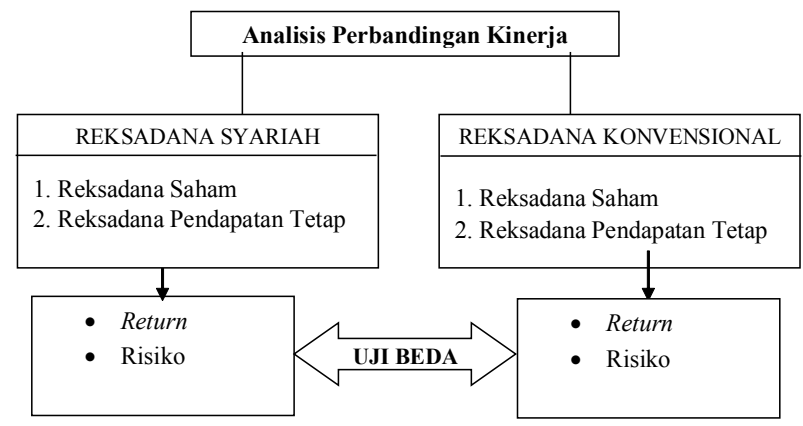

Gambar 3. Model Hipotesis Penelitian

\section{HASIL}

Sampai dengan periode 2010-2014, terdapat 42 reksadana saham konvensional yang masih tetap aktif dari tahun penerbitanya sebelum hingga 2014 kemudian ada 92 untuk reksadana pendapatan tetap konvensional. Selanjutnya untuk reksadana saham syariah yang tetap aktif sebelum tahun 2010-2014 terdapat 22 reksadana, sementara untuk reksadana pendapatan tetap syariah terdapat 8 . Dalam hal ini, dari sejumlah populasi tersebut dikeriteriakan dengan metode puposive sampling dan terpilih sebanyak 5 reksadana saham konvensional, 5 reksadana pendapatan tetap konvensional, 5 reksadana saham konvensional serta 3 untuk reksadana pendapatan tetap syariah yang memenuhi sebagai sampel penelitian. 


\section{Perbandingan Kinerja Reksadana Syariah dan Reksadana Konvensional}

Nurul Qomariah, Maheni Ika Sari, \& Dian Asib Budiarti

Hasil perhitungan rata-rata tingkat return reksadana selama periode penelitian ditunjukan pada tabel 1 berikut:

Hasil perhitungan risiko reksadana selama periode penelitian ditunjukan pada tabel 2 berikut

Pengujian normalitas dalam penelitian ini dilakukan berdasarkan analisis non parametrik kolmogorov-smirnov. Asumsi normalitas dapat dipenuhi jika nilai statistic kolmogorov-smirnov diatas tingkat signifikansi tertentu. Jika angka signifikan > 0,05 maka data berdistribusi normal dan apabila angka signifikansi $<0,05$ maka data tidak berdistribusi normal. Dari hasil uji normalitas terlihat bahwa nilai uji kolmogorov-smirnov untuk Reksadana Konvensional menunjukkan signifikansi diatas 0,05 atau 0,732 >0,05. Nilai Uji kolmogrov-smirnov untuk Reksadana Syariah menunjukkan signifikansi diatas 0,05 atau 0,107 >0,05. Sehingga data pada penelitian ini berdistribusi normal.

Uji hipotesis dilakukan dengan menggunakan uji Paired sampel T test (Uji beda sampel berpasangan), yaitu pengujian untuk mengetahui apakah ada perbedaan nilai dari satu sampel sebelum dan sesudah dilakukan perlakuan tertentu, namun menggunakan sampel yang sama dan pengambilan data 2 kali pada waktu yang berbeda. Apabila sig $>0,05$ maka tidak ada perbedaan, dan apabila sig < 0,05 maka terjadi perbedaan (Furqon, 2009). Dari hasil uji beda dengan Paired Samples Statistic dapat diketahui bahwa dengan 5 buah re-

Tabel 1 Hasil Perhitungan Rata-rata Return

\begin{tabular}{|c|c|c|}
\hline No & Reksadana Saham Konvensional & Rata-Rata Return \\
\hline 1 & Panin Dana Prima & 1.08 \\
\hline 2 & MNC Dana Ekuitas & 0.96 \\
\hline 3 & Dana Pratama Ekuitas & 0.95 \\
\hline 4 & Millenium Equity & 0.52 \\
\hline 5 & Pratama Equity & 0.37 \\
\hline No & Reksadana P.Tetap Konvensional & Rata-Rata Return \\
\hline 1 & Dana Obligasi Stabil & 0.66 \\
\hline 2 & Mega Dana Rido Tiga & 0.00 \\
\hline 3 & Simas Danamas Mantap Plus & 0.19 \\
\hline 4 & Prestasi Alokasi Portofolio Investasi (PAPI) & 1.00 \\
\hline 5 & Mega Dana Pendapatan Tetap & 0.12 \\
\hline No & Reksadana Saham Syariah & Rata-Rata Return \\
\hline 1 & BNP Paribas Pesona Syariah & 0.02 \\
\hline 2 & Trim Syariah Saham & 0.06 \\
\hline 3 & Manulife Syariah Sektoral Amanah & 5.38 \\
\hline 4 & Cipta Syariah Equity & 0.37 \\
\hline 5 & Batavia Dana Saham Syariah & 0.67 \\
\hline$\overline{\mathrm{No}}$ & Reksadana P.Tetap Syariah & Rata-Rata Return \\
\hline 1 & I-Haij Syariah Fund & 0.55 \\
\hline 2 & PNM Amanah Syariah & -0.10 \\
\hline 3 & BNI-AM Dana Syariah & 0.35 \\
\hline
\end{tabular}




\section{Jurnal Keuangan dan Perbankan | KEUANGAN}

Vol. 20, No.3, September 2016: 417- 427

turn reksadana saham konvensional mempunyai rata-rata return sebesar 0,7760 sedangkan reksadana saham syariah dengan jumlah reksadana yaitu 5 mempunyai mean sebesar 1.3000 dengan demikian kinerja reksadana syariah lebih baik di bandingkan dengan reksadana konvensional di lihat dari return. Begitu pula dengan Standar Deviasi dalam hal ini sama dengan risiko untuk reksadana saham konvensional sebesar 0,31101 sedangkan reksadana saham syariah lebih besar yaitu 2,29588, hal ini sesuai dengan paham high risk high return.

Dari hasil uji dengan Paired Samples Statistic dapat diketahui bahwa dengan 3 buah risiko reksadana pendapatan tetap konvensional mempunyai rata-rata risiko sebesar 3,6556 sedangkan reksadana pendapatan tetap syariah dengan jumlah reksadana yaitu 3 mempunyai risko rata-rata sebesar 0,9759 dengan demikian risiko pendapatan tetap konvensional lebih besar di bandingkan dengan risiko reksadana pendapatan tetap syariah. Dari nilai uji Paired Sampel T test dapat diketahui nilai Sig.(2-tailed) adalah 0,520 atau 0,520 $<0,05$. Hal ini berarti bahwa ada perbedaan yang signifikan terhadap risiko reksadana pendapatan tetap konvensional dengan risiko pendapatan tetap syariah. Berdasarkan hasil perhitungan, dapat disimpulkan bahwa hasil perhitungan risiko reksadana pendapatan tetap menunjukkan $\mathrm{T}$ hitung $(0,774)>$ T-tabel (2.91999). T - tabel diperoleh dari tabel titik presentase distribusi t dengan nilai d.f sebesar 2 dan nilai á sebesar 0.05. Nilai signifikansi yang diperoleh dari hasil perhitungan

Tabel 2 Hasil Perhitungan Risiko (Standar Deviasi)

\begin{tabular}{|c|c|c|}
\hline No & Reksadana Saham Konvensional & Standar Deviasi \\
\hline 1 & Panin Dana Prima & 1.02 \\
\hline 2 & MNC Dana Ekuitas & 1.48 \\
\hline 3 & Dana Pratama Ekuitas & 1.79 \\
\hline 4 & Millenium Equity & 1.05 \\
\hline 5 & Pratama Equity & 0.70 \\
\hline & & \\
\hline No & Reksadana P.Tetap Konvensional & Standar Deviasi \\
\hline 1 & Dana Obligasi Stabil & 1.79 \\
\hline 2 & Mega Dana Rido Tiga & 1.03 \\
\hline 3 & Simas Danamas Mantap Plus & 0.32 \\
\hline 4 & Prestasi Alokasi Portofolio Investasi (PAPI) & 1.73 \\
\hline 5 & Mega Dana Pendapatan Tetap & 0.44 \\
\hline No & Reksadana Saham Syariah & Standar Deviasi \\
\hline 1 & BNP Paribas Pesona Syariah & 0.26 \\
\hline 2 & Trim Syariah Saham & 0.24 \\
\hline 3 & Manulife Syariah Sektoral Amanah & 10.45 \\
\hline 4 & Cipta Syariah Equity & 0.55 \\
\hline 5 & Batavia Dana Saham Syariah & 1.38 \\
\hline No & Reksadana P.Tetap Syariah & Standar Deviasi \\
\hline 1 & I-Hajj Syariah Fund & 1.73 \\
\hline 2 & PNM Amanah Syariah & 0.29 \\
\hline 3 & BNI-AM Dana Syariah & 0.89 \\
\hline
\end{tabular}




\section{Perbandingan Kinerja Reksadana Syariah dan Reksadana Konvensional}

Nurul Qomariah, Maheni Ika Sari, \& Dian Asih Budiarti

adalah sebesar 0,520 dan lebih besar dari 0,520 $(0,520>0,05)$. Hal ini sesuai dengan kriteria keputusan bahwa dalam kondisi seperti ini hipotesa alternatif diterima, atau menunjukkan bahwa terdapat perbedaan antara kinerja reksadana reksadana pendapatan tetap konvensional dan reksadana reksadana pendapatan tetap syariah melalui risiko.

\section{PEMBAHASAN}

Hasil analisis data yang telah dilakukan pertama pada return reksadana saham konvensional dan return reksadana saham syariah bahwa terjadi perbedaan yang bermakna dimana rata-rata return reksadana saham syariah lebih tinggi dibandingkan dengan rata-rata return reksadana saham konvensional. Return yang tinggi juga berimbas pada semakin meningkatnya peminat reksadana syariah dari tahun ke tahun seperti yang disebutkan dalam Tandelilin (2001:47): "Return merupakan salah satu faktor yang memotivasi investor berinteraksi dan juga merupakan imbalan atas keberanian investor dalam menanggung risiko atas investasi yang dilakukannya", oleh karena itu akumulasi dana yang di kelola oleh reksadana saham syariah juga semakin besar. Hal ini terjadi karena (1) Solidnya kinerja saham-saham syariah secara keseluruhan. (2) Strategi manajer investasi Reksadana itu sendiri, seperti melakukan rotasi sektor saham yang potensial.

Kemudian hasil analisis data yang telah dilakukan kedua pada risiko reksadana pendapatan tetap konvensional dan risiko reksadana pendapatan tetap syariah membuktikan bahwa terjadi perbedaan yang signifikan antara keduanya, dimana risiko reksadana pendapatan tetap konvensional lebih rendah di bandingkan dengan risiko pendapatan tetap syariah. Dapat dikatakan bahwa kandungan risiko reksadana syariah melalui standar deviasi antara return realisasi dengan return ekspektasi masih dapat ditolerir atau masih dalam batas wajar, karena apapun investasi tetap memiliki risiko, sejalan dengan istilah "High Risk High Return". Penyebabnya adalah return pendapatan tetap syariah yang tinggi sehingga risikonya juga tinggi dalam hal ini manajer investasi kurang maksimal dalam mengurangi tingginya risiko dan tidak berhati-hati dalam membentuk portofolio reksadana. Sementara manajer investasi reksadana pendapatan tetap konvensional lebih konsisten dengan return lebih tinggi namun risiko rendah, dalam hal ini dapat dikatakan kinerja reksadana pendapatan tetap konvensional lebih baik.

Penelitian ini semakin di perkuat dengan penelitian yang dilakukan oleh Rachmawati (2008) memperoleh hasil bahwa kinerja produk reksa dana berbasis syariah lebih baik daripada kinerja reksa dana berbasis konvensional, hal ini dikarenakan jenis reksadana dan penggunaan data penelitian hampir sama yaitu dengan menggunakan NAB dari jenis reksadana kinerja reksa dana seperti reksadana saham, reksadana pendapatan tetap dan reksadana campuran baik konvensional maupun syariah sedangkan di dalam penelitian ini hanya menggunakan reksadana saham dan reksadana pendapatan tetap. Hasil penelitian Pasaribu (2011) juga menunjukan hasil yang tidak berbeda, dengan reksadana jenis yang sama menunjukan terjadi perbedaan meskipun tidak signifikan artinya reksadana syariah meskipun baru muncul di tahun 2003 telah dapat mensejajarkan kedudukannya dengan reksadana konvensional. Hasil penelitian ini juga sejalan dengan penelitian Putra dan Fauzie (2014) yang menyatakan bahwa tingkat pengembalian reksadana syariah lebih baik daripada reksadana konvensional, selain itu reksadana syariah memiliki risiko yang lebih kecil daripada reksadana konvensional.

Hasil berbeda ditunjukkan oleh Hamzah dan Yohanes (2014) berdasarkan uji beda terhadap return dan risiko yang menghasilkan tidak ditemukanya perbedaan signifikan antara kinerja reksadana syariah dan reksadana konvensional, namun disini return dan risiko yang di gunakan dari reksadana 


\section{Jurnal Keuangan dan Perbankan | KEUANGAN}

Vol. 20, No.3, September 2016: 417- 427

saham konvensional dan reksadana saham syariah saja yang artinya hanya menggunakan satu jenis reksadana dengan periode yang sama, sama halnya perbedaan hasil penelitian yang dilakukan oleh Arifianti (2011) dengan pengujian hipoteisis yakni terhadap reksadana campuran konvensional dengan reksadana campuran syariah dengan metode pengukuran menghitung berdasarkan laba total (total return) juga pengukuran risiko atau faktor risiko dari kedua jenis reksadana campuran tersebut menunjukan tidak terdapat berbedaan kierja secara signifikan antara reksadana campuran konvensional dengan reksadana campuran syariah. Hal senada dinyatakan oleh Rumintang dan Azhari (2014) bahwa antara kinerja reksa dana saham konvensional dan syariah tidak memiliki perbedaan yang signifikan.

Dari beberapa penelitian terdahulu yang mendukung penelitian ini di peroleh bahwa terdapat perbedaan yang signifikan antara reksadana saham dan reksadana pendapatan tetap konvensional dengan reksadana saham dan reksadana pendapatan tetap syariah melalui kinerja return dan risiko. Jadi hipotesis kedua yang menyatakan bahwa terdapat perbedaan yang signifikan antara kinerja reksadana syariah dan reksadana konvensional dengan risiko reksadana pendapatan tetap dapat diterima. Penelitian ini membuktikan bahwa kinerja reksadana konvensional dan reksadana syariah melalui return dan risiko dapat digunakan sebagai informasi dan bahan pertimbangan para investor reksadana yang akan menginvestasikan modalnya di reksadana.

\section{KESIMPULAN}

Dari analisis yang telah dilakukan pada kinerja reksadana saham konvensional dan reksadana saham syariah periode 2010-2014 menggunakan uji beda paired sample t-test menunjukkan bahwa terdapat perbedaan yang signifikan antara ratarata return reksadana saham konvensional dan rata-rata return reksadana saham syariah, hasil ini menjawab rumusan masalah dalam penelitian ini sekaligus sesuai dengan hipotesis pertama dimana perbedaannya adalah kinerja reksadana saham syariah lebih baik di bandingkan kinerja reksadana saham konvensional menunjukan bahwa rata-rata return reksadana saham syariah lebih besar dari pada rata-rata return reksadana konvensional.

Kinerja reksadana pendapatan tetap konvensional dan reksadana pendapatan tetap syariah periode 2010-2014 menggunakan uji beda paired sample $t$-test juga menunjukkan bahwa terdapat perbedaan yang signifikan melalui risiko reksadana pendapatan tetap konvensional dan reksadana pendapatan tetap syariah hal ini juga sesuai dengan hipotesis kedua bahwa reksadana pendapatan tetap konvensional memiliki risiko lebih tinggi di bandingkan reksdana pendapatan tetap syariah karena rata-rata risiko pendapatan tetap konensional memiliki angka lebih besar dibandingkan rata-rata risiko reksadana pendapatan tetap syariah, hal ini berarti kinerja reksadana konvensional lebih baik dibanding dengan kinerja reksadana syariah dalam risiko.

\section{SARAN}

Bagi para investor sebelum memutuskan untuk berinvestasi di reksadana jenis apapun sebaiknya terlebih dahulu melihat return dan risiko dari setiap reksadana untuk mengetahui reksadana mana yang lebih baik sebagai pilihan untuk berinvestasi. Bagi manajer investasi lebih baik terus meningkatkan kinerja untuk produk-produk reksadana yang di kelola sehingga dapat memberikan yang terbaik bagi investor. Mengenai prospek ke depan, diharapkan bahwa industri Reksa Dana syariah masih potensial karena produk syariah yang masih relatif sedikit memberikan peluang untuk dikembangkan, selain itu didukung oleh bertambahnya Daftar Efek Syariah (DES) yang menjadi acuan Manajer Investasi, seperti ISSI (Indeks Saham Syariah Indonesia). Ditambah lagi, dari sisi dana kelolaan, Reksa Dana saham syariah juga menunjukkan pertumbuhan yang cukup tinggi dari tahun ke tahun. 


\section{Perbandingan Kinerja Reksadana Syariah dan Reksadana Konvensional}

Nurul Qomariah, Maheni Ika Sari, \& Dian Asib Budiarti

\section{DAFTAR PUSTAKA}

Anwar, Khoirul, 2010. Pengaruh Tingkat Inflasi, Suku Bunga Sbi, Kurs, Dan IHSG Terhadap Kinerja Reksadana Saham. Laporan Penelitian. Surabaya: Sekolah Tinggi Ilmu Ekonomi PERBANAS.

Arifianti, Zariah, 2011. Komperasi Kinerja, Risiko Dan Return Reksadana Konvensional Dengan Reksadana Dengan Reksadana Syariah Di Bursa Efek Indonesia (BEI). Laporan Penelitian. Jember: Universitas Muhammadiyah Jember.

Hamzah dan Yohanes, 2014. Analisis Perbandingan Kinerja Reksadana Syariah Dengan Reksadana Konvensional Jenis Saham Pada Periode 20082012. Jurnal MIX, Vol. IV, No. 3, Oktober.

Hayati dan Haruman, 2006. Analisis Perbandingan Kinerja Reksadana Konvensional dan Reksadana Syariah Sebagai Dasar Pengetahuan Bagi Pengambilan Keputusan Investasi Di Pasar Modal Indonesia. Laporan Penelitian. Universitas Widyatma.

Karetini dan Rico Febriyanto, 2011. Analisis Perbandingan Kinerja Reksa Dana Konvensional Dengan Kinerja Reksa Dana Syariah. EfEktif Jurnal Bisnis dan Ekonomi Vol. 2, No 1, Juni 2011, 1 - 16.

Nindyaswara, Atilia Nini, 2014. Analisis Faktor-Faktor Yang Mempengaruhi Kinerja Reksadana Saham Di Indonesia Periode Tahun 2011-2013, Laporan Penelitian. Universitas Diponegoro Semarang.

Pasaribu, Iin Qarina, 2011. Analisis Perbandingan Kinerja Reksa Dana Syariah Dengan Reksa Dana Konvensional. Laporan Penelitian. Medan: Universitas Sumatera Utara.

Putra, Jepryansyah P dan Syarief Fauzie, 2014. Analisis Perbandingan Kinerja Reksa Dana Konvensional Dengan Reksa Dana Syariah Di Indonesia. Jurnal Ekonomi dan Keuangan Vol.2 No.5.
Rachmayanti, T. Farida, 2006. Analisis Kinerja Portofolio Saham Syariah Pada Bursa Efek Jakarta 2001-2002. Jurnal Ekonomi Keuangan dan Bisnis Islami, Vol. 2. No. 3, Juli-September.

Rumintang, Aprilia Grace dan Muhammad Azhari, 2014. Analisis Perbandingan Kinerja Reksa Dana Saham Konvensional Dan Reksa Dana Saham Syariah Dengan Menggunakan Metode Sharpe, Treynor, Dan Jensen Pada Tahun 2014. Jurnal_eproco.

Suciningtyas, Inayatul Hikmah, 2009. Perbandingan Kinerja Reksadana Syariah Dengan Reksadana Konvensional (Studi Danareksa Syariah Berimbang Dan Danareksa Anggrek Pada PT Danareksa Investment Management Periode 20052007). Laporan Penelitian. Universitas Sebelas Maret.

Sugiyono, 2009. Metode Penelitian Kuantitatif, Kualitatif dan $R \mathcal{E D}$, Bandung: CV Alfabeta.

Sukirno, Sadono, 1997. Pengantar Teori Mikro Ekonomi, PT. Rajawali Grafindo Persada, Jakarta.

Tandelilin, Eduardus, 2001. Analisis Investasi dan Manajemen Portofolio. Edisi Pertama. Yogyakarta: BPFE.

Undang-Undang Nomor 8 Tahun 1995 Tentang Pasar Modal (Lembaran Negara Th. 1995 No. 64, Tamabahan Lembaran Negara No.3608).

$\underline{\text { http://lipsus.kontan.co.id }}$

https://www.infovesta.com

http://www.bapepam.go.id 